\section{CJLT RCAT}

Canadian Journal of Learning and Technology

La Revue canadienne de l'apprentissage et de la technologie

Volume 47 (4)

Special Issue 2021

\title{
Learning Leaders: Teaching and Learning Frameworks in Flux Impacted by the Global Pandemic
}

\section{Leaders en d'apprentissage : cadres d'enseignement et d'apprentissage en flux influencés par la pandémie mondiale}

\author{
Margaret J. Cox, King's College London \\ Barry F. Quinn, King's College London
}

\begin{abstract}
This article builds on the work of EDUsummIT2019's thematic working group 2 (TWG2) focus on "Learning as Learning Leaders: How does leadership for learning emerge beyond the traditional teaching models?" Using the well-established theoretical frameworks of Entwistle (1987) and Shulman (1987) the most significant influences on how learning leaders need to adjust to accommodate the dramatic increase in remote online learning are identified. The major influences include learners' previous knowledge, self-confidence, abilities and motives, and changes between learning initiated by teachers and that by learners.

COVID-19 has caused a massive upskilling of people in all facets of society from children to grandparents, from media to consumers, and from policy makers to practitioners. None of the alignments nor factors identified in this article are static and learning leaders need to perpetually reconsider the factors identified to achieve successful learning outcomes. The ongoing challenges for educators in this changing world are in a permanent state of flux with an increasing IT literate society across all formal and informal sectors of education.
\end{abstract}

Keywords: Learning leaders; Theoretical frameworks; Pandemic impact; Educational re-alignments

\section{Résumé}

Cet article s'appuie sur le travail du TWG2 d'EDUsummIT2019, qui s'est concentré sur "L'apprentissage en tant que leaders d'apprentissage : Comment le leadership en matière d'apprentissage émerge-t-il au-delà des modèles d'enseignement traditionnels ?" En utilisant les cadres théoriques bien 
établis d'Entwistle (1987) et Shulman (1987) nous avons repéré les influences les plus significatives sur la façon dont les leaders d'apprentissage doivent s'adapter à l'augmentation spectaculaire de l'apprentissage en ligne réalisé à distance. Il s'agit, entre autres, des influences majeures sur les connaissances antérieures, la confiance en soi, les habiletés et les motifs des apprenant·e·s, ainsi que des changements entre l'apprentissage initié par les enseignant·e·s et celui initié par les apprenant·e·s.

L'un des avantages identifiés est que la COVID-19 a entraîné une montée en compétence numérique massive des personnes dans toutes les sphères sociétales, des enfants aux grands-parents, des médias aux consommateurs, et des décideurs politiques aux praticiens. Aucun des alignements ou des facteurs repérés dans cet article n'est statique et les leaders d'apprentissage doivent reconsidérer en permanence ces facteurs pour obtenir de bons résultats d'apprentissage. Les défis que doivent relever les éducateur·rice-s dans ce monde en mutation sont en constante évolution, avec une société de plus en plus informatisée dans tous les secteurs formels et informels de l'éducation, ce qui, avant la COVID-19, dépassait nos attentes les plus folles.

Mots-clés : Leaders d'apprentissage ; Cadres théoriques appliqués au numérique ; Impact de la pandémie ; Réalignements éducatifs

\section{Introduction}

EDUsummIT2019's Working Group 2 (TWG2) identified an important broadening of contexts for learning across the world. This has increasingly been facilitated by pervasive learning technologies, mainly involving what is frequently referred to as technology enhanced learning (TEL), usually applied in formal educational settings. Laurillard et al. (2009) defined TEL as any computer-based technology used for learning, including virtual reality (Luo et al., 2021), inside and outside formal learning contexts which can be stationary or mobile, depending upon the devices being used by individuals and groups of learners. Previous researchers demonstrated that the use of TEL in different educational settings, especially online learning, resulted in changes in leadership for learning (Laferrière \& Breuleux, 2002; Fisser \& Phillips, 2020). TWG2 showed that amongst learners and leaders

there is a lack of shared principles or guidelines for understanding learning, leading, IT (TEL), and change. This is accompanied by conflicting understandings of student success and wellbeing: competitive versus collaborative views of learning, making the grades versus having deep understandings (Fisser \& Phillips, 2020, p. 16).

TWG2 concluded that currently there is a general lack of coherent connections between policy, research, and teaching practices which makes progress in this area very slow and incomplete.

This article is focussed on how the current context and increased use of TEL has changed the opportunities for learning leaders and the subsequent changes in alignments between learners, leaders, and learning. The evidence used is based upon research which includes: (a) well-known substantial sources spanning more than 50 years (88 chapters: 27 countries) presented in the International Handbook of Information Technology in Primary and Secondary Education (Voogt \& Knezek, 2008); 
(b) the second edition of the International Handbook of Information Technology in Education (Voogt et al., 2018); (c) relevant articles published in this journal; and (d) articles reporting on the initial research findings of COVID-19 impact on education during 2020 and early 2021. Research into leadership in education over many years can be considered broadly at three different levels where TEL is concerned: (a) leadership for IT in education at an institutional macro level (Dexter, 2018); (b) the meso level of teaching and learning communities (Rogoff et al., 2018; Laferrière, 2017); and (c) at the micro level, the individual learner taking control of their learning (Jones et al., 2018). The foci of this article, which are on the learning leaders, what factors affect their learning and leadership, and how their roles as learners and learning leaders are changing, builds on TWG2's categorization of learning leaders, which includes teachers, students, and other educators in both formal and informal settings (Fisser \& Phillips, 2020).

At the institutional macro level, learning leaders, such as school district IT advisors, school principals and departmental heads, have to consider and implement the conditions that foster TEL uptake and use within formal educational settings. Their primary aims are to facilitate access, training, and the development of educators to achieve their educational visions and teaching objectives. However, with the balance between formal and informal learning changing over recent years as a result of the ubiquitous access to TEL in society, at the meso level, the roles of learners and their relationship with learning leaders are changing from the traditional learner-teacher relationship in both formal and informal contexts (Wong \& Ng, 2020). These roles will, however, also be influenced by the culture and policies of individual countries which vary, not only in their use and uptake of TEL, but in the way formal education is managed and delivered (Eickelmann, 2018; Fisser \& Phillips, 2020; Jiang et al., 2021). Furthermore, since the onset of the COVID-19 pandemic, these changes have been accelerated nationally and globally. TWG2 identified the following key guiding principles and underlying assumptions about leadership for learning and TEL:

- lead learners need to interact collaboratively, build relationships and trust, and ensure continuous development; and

- leadership for learning is distributed amongst participants and dependent on the opportunities present in different situations (Fisser \& Phillips, 2020, p. 16).

The group concluded that:

researchers, in partnership with technology providers and developers, can help develop further practices that integrate digital tools' unique potential ...that make learning visible and recognizable for oneself and for others (beyond grades), that allow differentiation and varied ways of engaging in learning and leading, etc. (Fisser \& Phillips, 2020, p.18).

Many factors influence learning, and these factors are elaborated on in the next section.

\section{Learning Frameworks and Influencing Factors}

As a result of the onset and massive impact of COVID-19, new models for learning leaders are emerging which only a year ago were not so prominent and in many educational settings would not have applied. Learners do not work in isolation, even remotely, and there are many factors which will influence their experiences, and consequently, their learning opportunities and roles as learning leaders. 
Remote and online learning have been around since the 1970s (Cox, 1983), firstly in higher education, where traditional learning leaders, i.e., academics, have had almost complete autonomy over curriculum design and control of the teaching and learning processes according to individual disciplines. Much of the published evidence from this sector also has relevance in the primary and secondary school sectors because in both contexts authority figures such as lecturers or teachers led the learning using national curricula or degree programmes.

Laferrière and Breuleux (2002) conducted an extensive study of leadership issues and challenges faced by professional educators working in a "Telelearning" environment where they were connected online. They found that leadership issues were clustered around beginning, mastery, and advanced levels of users. For successful use of TEL they found that there was "the need to use technology within a transformative vision of learning and to support with technology the new learning that could barely take place prior to the advent of networked computers" (Laferrière \& Breuleux, 2002, p. 336). Their study showed that the learning leaders/professional educators needed to change their visions of how learning would take place within a TEL environment compared with previous traditional teaching and learning settings.

In a more recent study by Banerji (2016), who conducted an extensive review of published research into the uptake, adoption, and integration of online learning in higher education (HE), the author identified the following barriers, opportunities, and issues: learners having inadequate or little access to the Internet; new communities of learners being facilitated by online access to knowledge; and the priorities for online instructor roles having to change to make online learning effective. These issues are now also relevant to those in compulsory K-12 education, which during the 18 months has been delivered regularly in many countries through remote learning online. Since Banerji's (2016) review, research confirms that there are still learners in many countries with limited access to the Internet for remote learning. The recent report by Hussar et al. (2020) on the condition of education in 2020 in the United States reported that over $90 \%$ of children between ages 3-18 had access to the Internet; the highest access being amongst the more educated families. In contrast, Internet access data reported by Merritt et al. (2020) show that globally on average only 54\% of citizens had access to the Internet and it was very unequal across countries, regions, and districts. Furthermore, as is discussed later, the uptake of TEL, where using the Internet is required, is still dependent upon government policies, teachers' confidence, and pedagogical understanding. Access to TEL and the Internet, especially in the current pandemic situation, is not however, the only factor to affect students' learning and learning leaders (Voogt et al., 2018). Entwistle (1987) developed a widely used framework, later expanded by Entwistle and Petersen (2004), which identified the relationships between student characteristics, the quality of the learning achieved, the teaching and learning environment, and teachers' subject knowledge and pedagogical beliefs.

This framework, shown in Figure 1, has been used by numerous researchers to identify the pertinent factors which can affect students' learning, most of which apply equally in primary and secondary education as well as higher education (San Diego et el., 2012). In relation to learning leaders, the factors shown in the model, modified to include those traditionally applying to secondary and 
primary schools are: (a) those at the institutional level, i.e., academic community and validating bodies, departments, and institutions; (b) those teaching and learning communities: university/school teachers' subject knowledge and pedagogical beliefs influencing how the teaching-learning environment might be designed; and (c) the learners themselves influenced by the student characteristics shown in Figure 1 such as previous knowledge, self-confidence, abilities and motives, approaches to learning, etc. In a less frenetic era, substantial research evidence has shown that the traditional teacher can accommodate new educational challenges by developing their understanding of their own pedagogical knowledge (Shulman, 1986, 1987) and the relationship between their pedagogical practices, students' attitudes towards learning, and the affordance which IT can provide (Webb \& Cox, 2004).

\section{Figure 1}

Conceptual Framework Showing Influences on Student Learning (Entwistle, 1987; Entwistle \& Peterson, 2004)

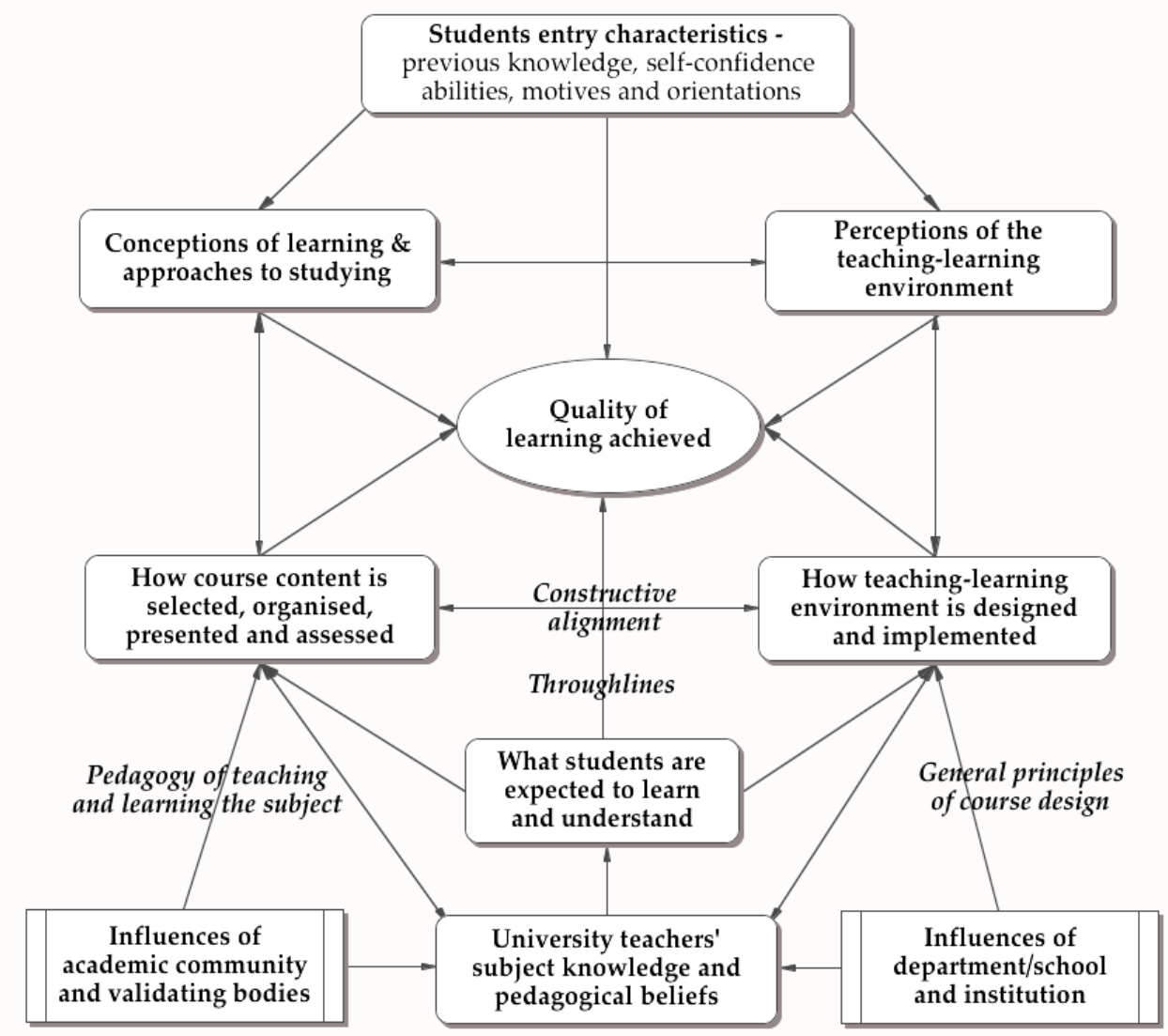

Figure 2 shows Shulman's pedagogical reasoning framework which has been expanded to show the connections between teachers' knowledge, beliefs, attitudes, and values affecting their pedagogical reasoning and subsequent behaviours and remote learning. The evidence from the literature shows the important roles which teachers need to adopt in enabling learners to engage in challenging TEL activities. In this affordance model, the influence of the teacher on the learning process is shown by the network of connections and the subsequent influence on learning outcomes, including the learning 
context and how assessment feeds back into students' learning. The greater use of TEL and remote online learning will further influence the learning contexts and consequently students' behaviours.

\section{Figure 2}

Shulman's (1987) Model of Pedagogical Reasoning (modified)

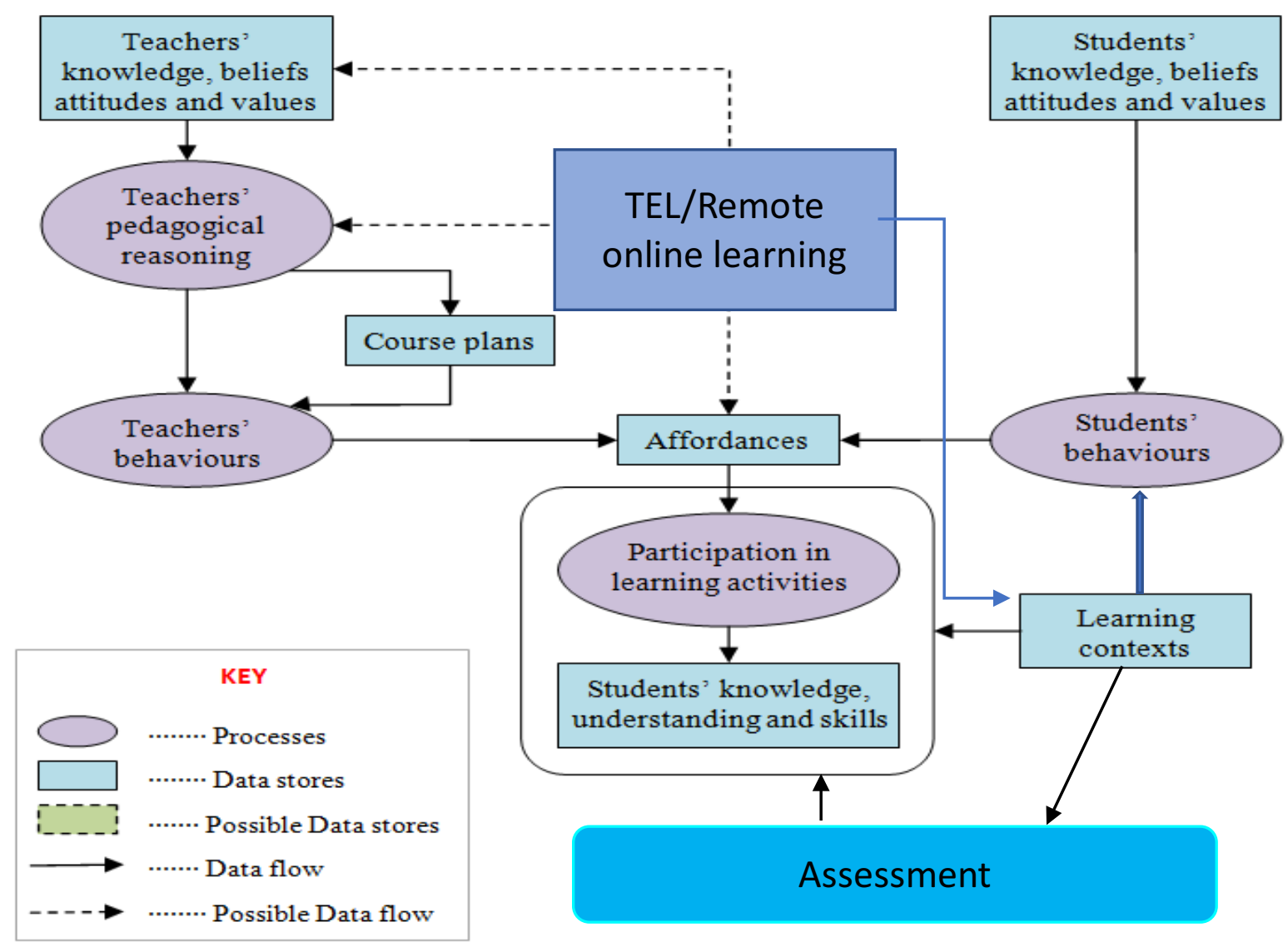

In the case of blended learning environments which are now becoming the new norm for education at many schools and higher education institutions, Lafortune and Lakhal (2020) identified four Community of Inquiry presences in a study of nursing undergraduate students. They found that the teaching, social, cognitive, and learner presences differed between those being taught face-to-face, compared with those at a distance. These results provide lessons for researching school education and new communities of learners where previously, in 2019 and earlier, relatively few children globally were learning online.

The range of pedagogical practices and challenges identified in previous research studies (Voogt et al., 2018) have now been seriously perturbed by the onset of COVID-19. Changes to teaching and learning methods, resources, and environments has become a compulsion and has been thrust upon the educational communities by COVID-19. The purpose of this article is to identify the changes taking place as reported in these and other studies to determine how the established theoretical frameworks 
shown in Figures 1 and 2 and the alignments might change and consequently impact learning leaders to take account of the uncertain educational future which lies ahead.

The objective has been to build on the well-established and tested theoretical frameworks depicted in Figures 1 and 2, together with recent research into the impact of COVID-19 using these methodological strategies to accomplish the following:

1. Review the most recent global studies of the factors in these frameworks which are now coming to the fore due to COVID-19 referred to above and by recent research.

2. Identify the most important influences briefly discussed in the introduction above for formal, informal, proximate, and distance learning.

3. Identify the factors which facilitate and inhibit the changes for learning leaders from a review of available published data.

\section{Impact of COVID-19 on Educational Urgency and Contexts}

As a result of cataclysmic changes in the ways schools, colleges, and universities have operated during 2020, the unforeseen impact on learners and teachers is still being grappled with. This has implications for learning and learning leaders both nationally and across different countries. A study by Basilaia and Kvavadze (2020) on the impact of the pandemic on schools across the globe, shows the proportion of schools which were closed, some for just two weeks and some for lengthier indefinite periods, with no predetermined decision about further lockdowns of schools (Figure 3 ).

\section{Figure 3}

Snapshot (4/4/2020) of Countries that have Shut Down or Localized the Schools in the World (https://en.unesco.org/covid-19/education response)

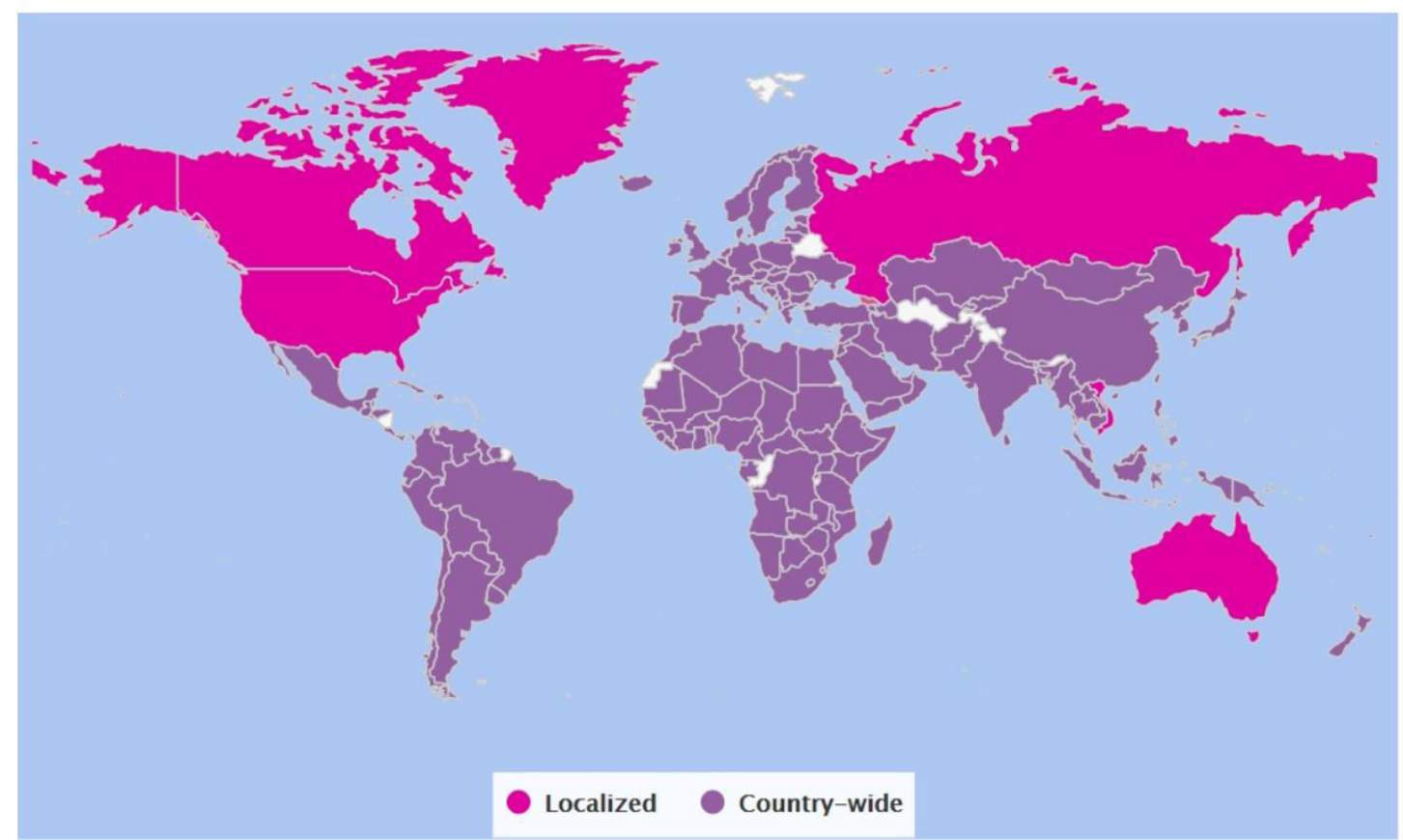


By April $4^{\text {th }}, 2020,188$ countries had shut down schools as one can see on the map affecting 1,576 million children globally. Ninety-six of these countries listed by UNESCO have adopted new ways of attempting to continue delivering the curriculum by remote learning. Delivery methods included online libraries, TV and radio broadcasts, guidelines sent through the post, resources, video lectures, and online channels.

Basilaia and Kvavadze (2020) investigated the strategies adopted by one private school in Georgia which, after all their schools were closed, immediately switched to remote learning while still maintaining the same school timetable and keeping the students' experience as close to the face-to-face in-school experience as possible. They found that the school timetable and structure of the lessons were kept similar to those before the start of the pandemic to ensure the least disruption to the teachers and the students. Assessment was conducted by the teachers through online forms at the end of every lesson.

A similar approach was used by The Perse School in Cambridge in the United Kingdom (UK) as well as by many other UK private schools. The Perse secondary school with students ages 11-18 continued in a similar mode to its in-school programme, but at a distance during the first lockdown (Perse School, 2020). In this example, all lessons were delivered through the existing school e-learning platform. These two examples in different countries show that learning leaders remained the teachers with little change reported in terms of the learners controlling their own learning or collaborative learning communities.

This educational approach, mirroring the traditional school setting, but at a distance, has not however been adopted universally in the majority of schools across the globe (UNESCO, 2020). A contrasting example was reported by Sintema (2020), who, after the schools in Zambia were closed, conducted telephone interviews with three teachers in STEM education in the Chipata district. In Zambian schools, teachers' explanations to help students learn are highly valued and this support could not be maintained remotely with some students having very little access to online learning or even to reliable electricity supplies. The teachers believed that those pupils who were less able to work effectively on their own would be negatively affected by remote learning compared with pupils who could work alone. The researcher concluded that because science teaching involves laboratory work and is more costly than many other school curriculum subjects, the implementation of the STEM curriculum in schools would be adversely affected. This was a likely outcome, not only during the pandemic, where there were no laboratory sessions taking place, but afterwards, because the curriculum "is expensive to implement and the state of the national economy after COVID-19 would not have the muscle to fully support these schools" (Sintema, 2020, p. 6). This research identified another factor not yet reported widely in the education literature, that is: the effects of COVID-19's ravaged economies will damage the future of educational practice in schools and colleges.

At the opposite end of the country scale, China took a different approach. China has reported relatively few new COVID-19 cases since April $15^{\text {th }}, 2020$, proportionate to its population (see https://www.worldometers.info/coronavirus/country/china/). With a population of over 220 million children, the Chinese government closed all schools very early on in the pandemic and adopted a policy of integrating national resources and planning at the top governmental level (Zhang et al., 2020). The 
government took action to guarantee the provision of network service resources to provide fast and stable networks for online education, and teachers', students', and parents' access to TEL. It also worked on making educational resources accessible to the public to provide free high-quality online courses and virtual simulation experimental teaching resources. Efforts were also made to increase society's participation in online education. However, according to the researchers, even though one of the government's aims was to cultivate students' independent learning abilities, in such a large country it was not possible to provide this high standard to all. They concluded that there was an urban-rural disparity, different levels of knowledge about information technology acquired by teachers, and teachers' differing attitudes towards and ability to learn information technology skills, which would all have an impact on the general effectiveness of online education across the country (Zhang et al., 2020).

A further study conducted in China by Wang et al. (2020) found that when children were out of school during weekends and summer holidays, they were physically less active, had much longer screen time, irregular sleep patterns, and less favourable diets. Such negative effects on health were considered likely to be much worse when children are confined to their homes without outdoor activities and interaction with same-aged friends during the outbreak. These studies show that although great effort was made by the Chinese government to provide good remote educational resources for learners working from home, the learning context in many homes was not conducive to effective learning.

In conclusion, the impact of COVID-19 on the delivery of education in schools, despite UNESCO's long list of guidelines for all governments across the globe, a survey by Reimers and Schleicher (2020) assessing the needs of 98 countries for UNESCO found that for the 75 countries which responded ( $<4$ responses per country), when asked what their country was doing for them to support ongoing academic work responded 'nothing'. Furthermore, these reviews presented here did not take account of all the additional barriers identified and reported by schools in the media. These have included reports about teaching staff being ill so they were not engaged in online teaching, students and parents having no computer at home nor computer access, restricted home environment to peaceful study due to large families in small apartments, inadequate IT skills amongst learners, teachers and parents, and other home and informal challenges. These recent studies show that a major impact on learning leaders has come from governments at the institutional meso level but assumptions have been made about the delivery of education being possible at a distance in spite of teachers' limited experience and skills for this enforced rapid change. How this change has impacted new challenging learning contexts leading to new alignments is discussed in the next section.

\section{Learning Leaders: New Contexts and Alignments}

As discussed above, changes to leadership for learning has been influenced by government policies, school practices, and teachers' abilities to change and embrace TEL for remote learning. To examine the changing educational alignments resulting from the enforced rapid adoption of TEL and the impact of COVID-19 discussed above, we reconsider the frameworks of Entwistle and Peterson (Figure 1) and Shulman (Figure 2).

The variables identified by Entwistle and Peterson (2004) fall into three broad categories which are listed in Table 1: students' characteristics, teachers' pedagogical beliefs and practices, and 
institutional influences with the alignments shown between them (Figure 1). For example, in Table 1 an individual student's characteristics (column 1) such as previous knowledge, self-confidence, abilities and motives will affect their approaches to learning and studying and consequently to the quality of the learning achieved. In traditional settings this has been aligned with, amongst other factors, how the course content is selected, organized, presented, and assessed (column 2). Similarly, the institutional influences (column 3) determine the choice of the curriculum, how the curriculum is delivered, and how it is validated.

In Shulman's modified framework (Figure 2) similar alignments are identified between students' knowledge, beliefs, attitudes and values, their behaviours, and affordances which then influence their participation in the learning activities. The impact of remote online learning, which has been shown above to affect the learning contexts, students' behaviours and teachers' beliefs etc., will also change the alignments between the teacher as the learning leader and the individual learner.

\section{Table 1}

Entwistle and Peterson's Framework Variables (traditional teaching and learning environment)

\begin{tabular}{lll}
\hline Students' characteristics & $\begin{array}{l}\text { Teachers' pedagogical beliefs and } \\
\text { practices }\end{array}$ & Institutional influences \\
\hline $\begin{array}{l}\text { Previous knowledge, self- } \\
\text { confidence, abilities, and motives }\end{array}$ & $\begin{array}{l}\text { How course content is selected, } \\
\text { organised, presented, and assessed }\end{array}$ & $\begin{array}{l}\text { General principles of course } \\
\text { design }\end{array}$ \\
$\begin{array}{l}\text { Previous experience of teaching } \\
\text { and learning }\end{array}$ & $\begin{array}{l}\text { How teaching-learning environment } \\
\text { is designed and implemented }\end{array}$ & $\begin{array}{l}\text { Influences of department/school } \\
\text { and institution }\end{array}$ \\
$\begin{array}{l}\text { Conceptions of knowledge and } \\
\text { learning }\end{array}$ & $\begin{array}{l}\text { What students are expected to learn } \\
\text { and understand }\end{array}$ & $\begin{array}{l}\text { Influence of academic community } \\
\text { and validating bodies }\end{array}$ \\
$\begin{array}{l}\text { Approaches to learning and } \\
\text { studying }\end{array}$ & $\begin{array}{l}\text { Teachers' subject knowledge and } \\
\text { pedagogical beliefs }\end{array}$ & $\begin{array}{l}\text { Choice and delivery of the } \\
\text { curriculum }\end{array}$ \\
$\begin{array}{l}\text { Instructional conceptions } \\
\text { Perceptions of teaching-learning } \\
\text { environment }\end{array}$ & & \\
\hline
\end{tabular}

Since these frameworks were first published, we have seen an enormous step up in the adoption of TEL due to COVID-19. This change was expected by some researchers to have been made much earlier, not because of the pandemic but because it was believed by pioneers (e.g., Cox, 1983, 1987; Cox $\&$ Marshall, 2007) more than 30 years ago that governments and educators would move much more rapidly from a mainly traditional face-to-face learning environment to a mainly e-learning environment as depicted in Figure 4 below (Cox \& Sakamoto, 2011). This shows the then 'present stage' which was mainly 'traditional face-to face learning' moving to the future stage where 'e-Learning' (TEL) was predicted to be the main practice for all education systems in the foreseeable future. Now, finally, because of the impact of the pandemic resulting in the move to remote online learning discussed earlier, for many learners and learning leaders we are possibly only temporarily in the future stage. 


\section{Figure 4}

Present and Future Stages in e-Learning (Cox \& Sakamoto, 2011)

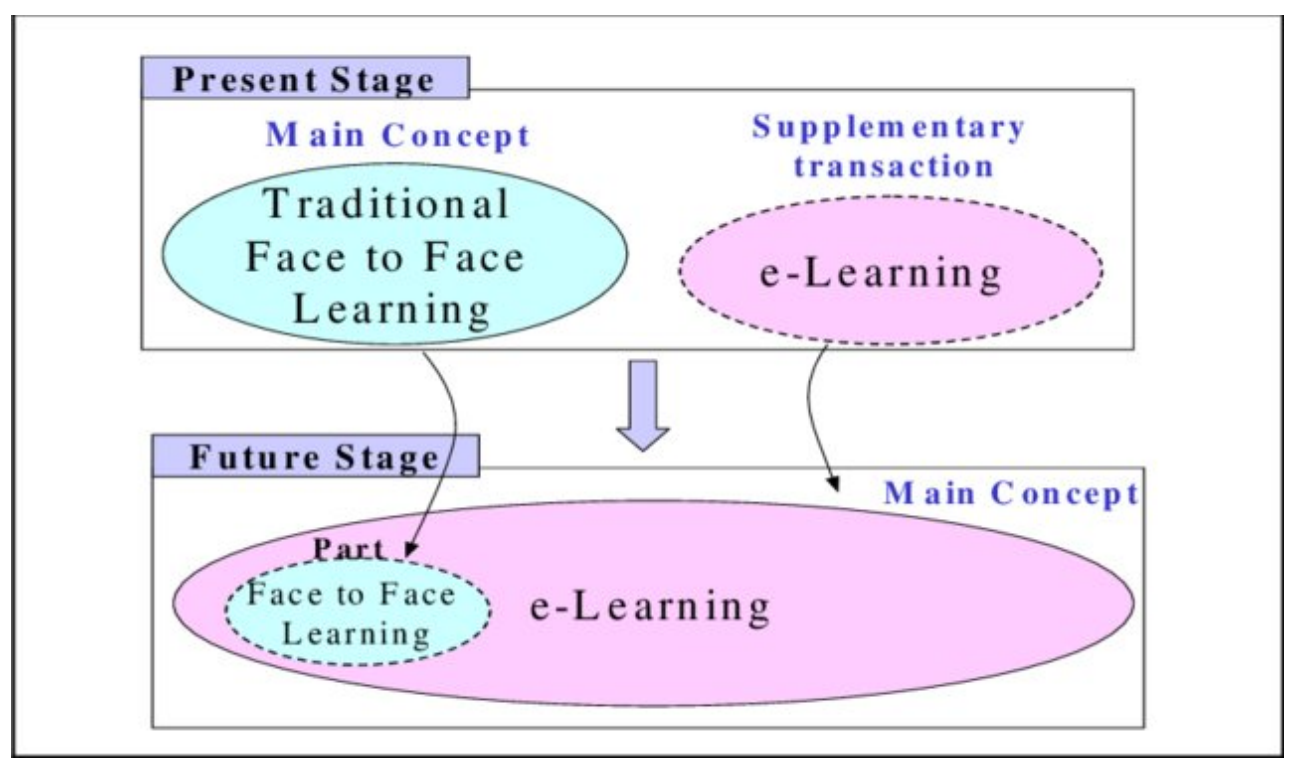

Cox et al. (2013) in a review of the literature for EDUsummIT2011 identified these challenges and unresolved questions for researchers, which according to the most recent research (Fisser \& Phillips, 2020; Voogt et al., 2018) still pertain to the present time. For example, would the same TEL resource used in a secondary science classroom in which most pupils have mobile phones have the same impact on students' learning as in one where electricity supplies are intermittent, and the IT resource costs the same as a teacher's salary? Furthermore, TEL provides new dynamic knowledge representations as the technology evolves. The alignments between learners and teachers in this example is depicted by Entwistle and Peterson's (2004) framework showing that students' and teachers' perceptions will interpret knowledge presented through TEL differently and therefore there may be the need to reconsider how knowledge is being presented from the learning leader to the learner. Figure 2 shows that the affordances which learners have will also be affected by the learning contexts and their participation in their learning activities.

With regard to who are learning leaders in a connected and life-long learning world they might include any member of society in certain contexts, e.g., children, pupils, students, teachers, experts, civil servants, and parents (Laferrière \& Breuleux, 2002). Many of these groups can be considered as learning leaders which will change at all three levels identified earlier due to this remote/online/connected educational environment at the institutional, community, and individual levels. Finally, new literacies, which are perceptions and understandings linked to new modes of presentation and representations, are changing the emphasis and the balance in terms of the production, content and meaning of educational resources, which is often not understood by teachers. This implies that learning leaders will also be influenced by their abilities to understand and lead effectively with varied levels of IT skills and perceptions of new modes of knowledge representations. 
Other important factors which are also addressed by Entwistle's and Shulman's frameworks include the earlier work of Beaty et al. (1997) who introduced the term 'learning orientation' and defined it as all those attitudes and aims which express the student's individual relationship with a course of study and the university. They reviewed a range of empirical studies which linked student learning specifically to study behaviour. It is the collection of purposes which form the personal context for the individual student's learning and may be classified as academic, vocational, personal, and social. Summarizing these variables, the authors concluded that students' conceptions of knowledge, of learning and learning orientations develop and change during the learning process and within different learning environments.

Kumpulainen and Sefton-Green (2012) conducted an extensive literature review of connected learning and concluded that learning takes place within a matrix and continuum of several communities and contexts. Furthermore, the role of time and scale as well as spatiality online and offline are significant influencers of connected learning. They predicted that connected learning would be set to dominate progressive educational reforms but expanded learning environments that support connected learning could emerge only through sustained collective efforts.

Considering the factors identified above from previous extensive research studies, we return to the theoretical frameworks depicted in Figures 1 and 2 and Table 1 to examine how COVID-19 has accelerated such changes between learners and learning leaders. Relating these to the frameworks, the evidence above shows that the most important influences are:

\section{Previous Knowledge, Self-Confidence, Abilities and Motives}

Previous research has shown that these vary significantly not only from individual to individual but over time, depending amongst other factors, upon their exposure to the use of TEL, familiarity with its use, and their digital skills. Gormley et al. (2012) used Keller's ARCS (attention, relevance, confidence, satisfaction) framework for improving motivation through the use of instructional materials. They concluded that:

although many of the interpersonal aspects perceived when teaching students in the classroom are absent in the online learning environment, the core principle is the same: how to set the scaffolding - the strategies - to achieve student learning. With the expanding numbers of students enrolled in distance learning courses, active participation in learning, student-faculty interaction, and interaction with peers are critical to keeping students engaged in learning and motivated to participate in classes." (Gormley et al, 2012, p 180)

\section{Changes in Alignments Between Formal and Informal Learning}

Informal learning used to be regarded as outside the control of the teacher and institution (Cox, 2013), but with enforced home learning for millions of learners, as shown earlier, in many informal contexts the curriculum and educational development have still been mainly controlled by the teachers at a distance. They have, however, lost full control and influence on how the teaching-learning environment is designed and implemented in an informal setting, how their previous experience of teaching and learning is affected remotely, and what approaches to learning and studying are being 
adopted by every individual learner. Research discussed above has shown that once the traditional curriculum is delivered entirely remotely, the balance and interface between 'formal' and 'informal' will now depend more on government emergency strategies, parents' IT skills and resources at home, and learners' conceptions of knowledge and learning. Governments are now playing a more controlling role over institutions on how education is delivered, not only traditionally but since COVID-19 has made it a necessity (Tran et al., 2020).

\section{Changes Between Learning Initiated by Teachers and that by Learners}

The quality of learning achieved by learners will depend upon student characteristics such as previous knowledge, conceptions of knowledge and learning, as well as approaches to learning and studying. But we have also shown that in a TEL environment, which has been the dominant environment during school closures in many countries, it will also be challenged by technological barriers, perceptions of a TEL teaching-learning environment, and the spatiality online and offline which is different for every learner and every learning environment.

\section{Interface between Learning Controlled by On-site Teaching and Remotely}

As discussed above, this interface will not only be dependent upon how the blended learning is delivered by an educational institution, such as a school running a timetable and curriculum remotely, but it will also depend upon regular interactions between the teacher(s) and learners working at a distance. An additional challenge for teachers and institutions during 2020 has been that when learners have returned to educational establishments, teachers have had to reorganise their learning spaces and timetables for proximate teaching.

\section{Changes in Students' Perceptions of Knowledge and Learning}

For the majority of the worlds' learners, the evidence presented in this article has shown that connected learning changes the way students perceive and respond to what they are learning and how they acquire new knowledge. In the study referred to earlier on blended learning, LaFortune and Lakhal (2020) found that even within one cohort of 45 students, there were significant differences amongst their perceptions of the teaching, cognitive, and learning presences. Furthermore, a much earlier review by Beaty et al. (1997) concluded that students' conceptions of knowledge, learning and learning orientations develop and change during the learning process and within different learning environments. Furthermore, a very recent study by Chang (2020) shows that learners interact differently with learning material presented on a screen and their individual social presences will differ thereby affecting their conceptions of knowledge and learning.

\section{Students' Perceptions of the Teaching and Learning Environment}

In this article, we have presented past and current research which shows how the teaching and learning environments have changed drastically when schools and universities have moved to remote learning and even when re-opening schools, teachers and pupils still must maintain new socially distancing rules in proximate teaching. Entwistle (1987) showed that the individual perceptions of students will affect their approaches to learning and studying thereby affecting the quality of their 
learning achieved. At present, there has been insufficient time for researchers to investigate the full extent of changes in learners' perceptions as a result of education under COVID-19 restrictions.

\section{Individual Learners' Approaches to Learning and Studying}

Whilst the majority of learners across the world at compulsory school ages until 2020 were mostly still being taught by traditional onsite sessions with TEL components included from time to time, the individual learner's approaches to learning and studying varied greatly from one learner to another (Cox, 2013; Gormley et al., 2012). The additional perturbation of COVID-19 brings a further challenge for learners who now must learn new ways of learning and motivation to stay committed to learning programmes (Huang et al., 2020; Wong \& Ng, 2020).

\section{Pedagogy of Teaching and Learning the Subject}

Extensive research into teachers' pedagogies reported over the years has shown that, as depicted in Entwistle's and Shulman's frameworks, what teachers expect students to learn and understand will have a direct influence on how the teaching-learning environment is designed and implemented, teachers' subject knowledge and pedagogical beliefs, and how the course content is selected, organised, presented and assessed (Bawane \& Spector, 2009; Cox \& Webb, 2004; Jiang et al., 2021; Khine et al., 2019; Shulman, 1986, 1987 ). Now that COVID-19 has impacted the way government and institutions deliver education, teachers are facing new challenges by not only having to work in new ways such as blended and online learning, but in new contexts and with much reduced control of their students' learning experiences.

\section{Conclusion}

In contrast to all previous global research and educational practices in our lifetimes, we have shown that because of the pandemic there has been an unprecedented global government push towards blended and online learning for all. The original Entwistle model (Figure 1) acknowledges the influence of the academic communities, validating bodies, universities, and schools but the over-riding influence during this pandemic has emanated from governments closing schools and universities for varying amounts of time (UNESCO, 2020). Entwistle (1987) shows alignments between course content and how the teaching and learning environment is designed, but our review has revealed more emphatic alignments between course content and government agencies as a result of enforced government strategies. The question is: will this change the balance between proximate and remote learning and all that this would imply, once the pandemic has 'gone' back to the previous mainly traditional delivery methods? Because the pandemic situation is ongoing and therefore in a state of flux, the purpose of our review of past and present evidence has been to identify those factors which have clearly been perturbed by education in a COVID-19 world, and which are now providing an anchor of educational realignments in both formal and informal settings for leading learners.

Revisiting the first guiding principle of TWG2 from EDUsummIT2019 that "lead learners need to interact collaboratively, build relationships and trust, and ensure continuous development" our review 
has shown that the predominant remote learning which may be the status quo for some time will make this more challenging unless it is supported by regular professional development to address all the flexible skills and understanding required in these changing technological, social, and cultural settings. Re-examining the frameworks used in this article, we conclude that these realignments will change over time since with the changing contexts, skills, understandings and technological advancements are static and learning leaders need to reconsider perpetually the factors identified above to achieve successful learning outcomes.

In order for leadership for learning to be distributed amongst participants and learning communities, and to be dependent on the opportunities present in different situations then as a result of COVID-19, there will need to be new methods of regular communication amongst participants to ensure those opportunities are real and achievable. In the last year there has been a massive use of online communication networking software such as Zoom, Skype, MSTeams, etc. which, according to the media, have raised the IT communication skills of many of those now influencing education practice which will support this principle. One benefit from COVID-19 has been this upskilling of all facets of society from children to grandparents, from media to consumers, and from policy makers to practitioners. At every EDUsummIT gathering since 2009, there has been a call for the restructuring of schools to move them from the industrial age to the digital age (Resta et al., 2011). This has been accepted as a major undertaking that would require effective leadership and the engagement of all stakeholders. Perhaps as we now almost have an IT literate society across all sectors, this might be at last achievable. 


\section{References}

Banerji, S. (2016). Factors and barriers influencing the uptake of continuing professional development through distance education courses for professional dentists (Publication No. 10584319) [Doctoral dissertation, University of London King's College]. ProQuest Dissertations and Theses Global.

Basilaia, G., \& Kvavadze, D. (2020). Transition to online education in schools during a SARS-CoV-2 Coronavirus (COVID-19) pandemic in Georgia. Pedagogical Research, 5(4), Article em0060. https://doi.org/10.29333/pr/7937

Bawane, J., \& Spector, J. M. (2009). Prioritization of online instructor roles: implications for competency- based teacher education programs. Distance Education, 30(3). 383-397, https://doi.org/10.1080/01587910903236536

Beaty, E., Gibbs, G., \& Morgan, A. (1997). Learning orientations and study contracts. In F. Marton, D. J. Hounsell, \& N. J. Entwistle (Eds.), The experience of learning, (2nd ed., pp. 72-88). Scottish Academic Press. http://www.tla.ed.ac.uk/resources/EoL.html

Chang, C. -T. (2020). An analysis of discipline and personality in blended environments: Do they interact differently in the teaching, cognitive, and social presences? Canadian Journal of Learning and Technology, 46(1). https://doi.org/10.21432/cjlt27883

Cox, M. J. (1983). Case study of the application of computer based learning. In N.J. Rushby (Ed.), Computer based learning - State of the art report (pp. 31-46). Pergamon.

Cox., M. J. (1987). CAL and the Future in Plomp, T., Van Deursen, J., and Moonen, J. (Eds.), Computer Assisted Learning for Europe. Elsevier Science Publishing.

Cox, M. J. (2013). Formal to informal learning with IT: Research challenges and issues for e-learning. Journal of Computer Assisted Learning, 29(1), 85-105. https://doi.org/10.1111/j.13652729.2012.00483.x

Cox, M. J., \& Marshall, G. (2007). Effects of ICT: Do we know what we should know? Education and Information Technology, 12(2), 59-70. https://doi.org/10.1007/s10639-007-9032-x

Cox, M. J., Niederhauser, D. S, Castillo, N., McDougall, A. B, Sakamoto, T., \& Roesvik, S. (2013) Researching IT in Education. Journal of Computer Assisted Learning, 29(1), 474-486. https://onlinelibrary.wiley.com/doi/epdf/10.1111/jcal.12035

Dexter, S. (2018). The role of leadership for information technology in education: Systems of practices. In J. Voogt, G. Knezek, R. Christensen, \& K.W. Lai (Eds.), Second handbook of information technology in primary and secondary education, (pp. 1-16). Springer. https://doi.org/10.1007/978-3-319-53803-7 32-1 
Eickelmann, B. (2018). Cross national policies on information and communication in primary and secondary schools: An international perspective. In J. Voogt, G. Knezek, R. Christensen \& K.W. Lai (Eds.), Second handbook of information technology in primary and secondary education (pp. 1221-1380). Springer. https://doi.org/10.1007/978-3-319-71054-9_84

Entwistle, N. J. (1987). A model of the teaching-learning process. In J. T. E. Richardson, M. W. Eysenck, and D. Warren-Piper (Eds.), Student learning: Research in education and cognitive psychology (pp. 13-28). SRHE \& Open University Press.

Entwistle, N., \& Peterson, E. (2004). Conceptions of learning and knowledge in higher education: Relationships with study behaviour and influences of learning environments. International Journal of Educational Research, 41(6), 407-428. https://doi.org/10.1016/j.ijer.2005.08.009

Fisser, P., \& Phillips, M. (2020). EdusummIT E-book: Learners and learning contexts: new alignments for the digital age. https://edusummit2019.fse.ulaval.ca/files/edusummit2019_ebook.pdf

Gormley, D. K., Colella, C., \& Shell, D. L. (2012). Motivating online learners using attention, relevance, confidence, satisfaction motivational theory and distributed scaffolding. Nurse Educator, 37(4), 177-180. https://doi.org/10.1097/NNE.0b013e31825a8786

Huang, R. H., Liu, D. J., Tlili, A., Yang, J. F., Wang, H. H., et al. (2020). Handbook on facilitating flexible learning during educational disruption: The Chinese experience in maintaining undisrupted learning in Covid-19 outbreak. Smart Learning Institute of Beijing Normal University. https://iite.unesco.org/wp-content/uploads/2020/03/Handbook-on-FacilitatingFlexible-Learning-in-COVID-19-Outbreak-SLIBNU V2.0 20200324.pdf

Hussar, B., Zhang, J., Hein, S., Wang, K., Roberts, A., Cui, J., Smith, M., Bullock Mann, F., Barmer, A., \& Dilig, R. (2020). The Condition of Education 2020 (NCES 2020-144). U.S. Department of Education, National Center for Education Statistics. https://nces.ed.gov/pubsearch/pubsinfo.asp?pubid=2020144

Jiang, Y., Lee C-K. J., Wan, Z.H., \& Chen, J. (2021). Stricter teacher, more motivated students? Comparing the associations between teacher behaviors and motivational beliefs of western and east Asian learners. Frontiers in Psychology, 11, 564327. https://doi.org/10.3389/fpsyg.2020.564327

Jones, A., Scanlon, E., \& Charitonos, K. (2018). Learning across locations and settings. In R. Luckin (Ed). Enhancing learning and teaching with technology (pp.176-197). UCL IoE. Press.

Khine, M.S., Afari, E., \& Nagla, A. (2019). Investigating technological pedagogical content knowledge competencies among trainee teachers in the context of ICT course. Alberta Journal of Educational Research, 65(1), 22-36. https://doi.org/10.1037/t73466-000

Kumpulainen, K., \& Sefton-Green. J. (2012). What is connected learning and how to research it? International Journal of Learning and Media, 4(2), 8-18. http://dx.doi.org/10.1162/IJLM_a 00091 
Lafortune, A-M., \& Lakhal, S. (2020). Differences in students' perceptions of the Community of Inquiry in a blended synchronous delivery model. Canadian Journal of Learning and Technology, 45(3). https://doi.org/10.21432/cj1t27839

Laferrière, T. (2017). Les défis de l'innovation selon la théorie de l'activité : Le cas de l'école (éloignée) en réseau. Revue canadienne de l'éducation, 40(2), 1-30. http://journals.sfu.ca/cje/index.php/cje-rce/article/view/3110/2412

Laferrière, T., \& Breuleux, A. (2002). Leadership issues and challenges in telelearning and teacher education. Journal of Information Technology and Teacher Education, 11(3), 335-354. https://doi.org/10.1080/14759390200200143

Laurillard, D., Oliver, M., Wasson, B., \& Hoppe, U. (2009). Implementing technology-enhanced learning. In N. Balacheff, S. Ludvigsen, T. de Jong, A. Lazonder, \& S. Barnes (Eds.), Technology-enhanced learning (pp. 289-306). Springer. https://doi.org/10.1007/978-1-40209827-7 17

Luo, H., Li, G., Feng, Q., Yang, Y., \& Zuo, M. (2021). Virtual reality in K-12 and higher education: A systematic review of the literature from 2000 to 2019. Journal of Computer Assisted Learning, 115. https://doi.org/10.1111/jcal.12538

Merritt, J., Wylde, G., Bettinger, K, Mesirow, R., Yaung, D., \& Wang, W. (2020). State of the connected world 2020 edition: Insight report, December 2020. World Economic Forum in collaboration with the Global Internet of Things Council $(P w C)$. http://www3.weforum.org/docs/WEF The State of the Connected World 2020.pdf

Perse School. (2020) https://www.perse.co.uk/homelearn/.

Reimers, F. M., \& Schleicher, A. (2020). A framework to guide an education response to the COVID_19 Pandemic of 2020. https://globaled.gse.harvard.edu/files/geii/files/framework guide_v2.pdf

Resta, P., Searson, M., Patru, M., Knezek, G., \& Voogt, J. (2011). Building a global community of policy makers, researchers and teachers. Summary report of Edusummit2011 and Call to Action. Journal of Computer Assisted Learning.

Rogoff, B., Matusov, E., \& White, C. (2018). Models of Teaching and Learning. The Handbook of Education and Human Development (pp. 373-398).

https://doi.org:10.1111/b.9780631211860.1998.00019.x

San Diego, J., Cox, M. J., Quinn, B. F. A., Newton, J. T., Banerjee, A., \& Woolford, M. (2012). Researching haptics in higher education: The complexity of developing haptics virtual learning systems and evaluating its impact on students' learning. Computers \& Education. 59(1), 156166. https://doi.org/10.1016/j.compedu.2011.11.009

Shulman, L. S. (1986). Those who understand: Knowledge growth in teaching. Educational Researcher, 15(2), 4-14. https://doi.org/10.3102/0013189X015002004 
Shulman, L. S. (1987). Knowledge and teaching: Foundations of the new reform. Harvard Educational Review, 57(1), 1-23. https://doi.org/10.17763/haer.57.1.j463w79r56455411

Sintema, E. J. (2020). Effect of COVID-19 on the performance of grade 12 students: Implications for STEM education. EURASIA Journal of Mathematics, Science and Technology Education, 16(7) Article em1851. https://doi.org/10.29333/ejmste/7893

Tran, T., Hoang, A. -D., Nguyen, Y. -C., Nguyen, L. -C., Ta, N. -T., Pham, Q.- H., Pham, C.- X., Le, Q.A., Dinh, V. -H., \& Nguyen, T.-T. (2020). Toward sustainable learning during school suspension: Socioeconomic, occupational aspirations, and learning behaviour of Vietnamese students during COVID-19. Sustainability, 12(10), 4195. https://doi.org/10.3390/su12104195

UNESCO. (2020). Response to COVID 2020. https://en.unesco.org/covid19/educationresponse/nationalresponses

Voogt, J., \& Knezek, G. (2008). International handbook of information technology in primary and secondary education. Springer.

Voogt, J., Knezek, G., Christensen, R., \& Lai, K-W. (2018). Second international handbook of information technology in primary and secondary education. Springer.

Wang, G., Zhang, Y., Zhao, J., Zhang, J., \& Jiang, F. (2020). Mitigate the effects of home confinement on children during the COVID-19 outbreak. The Lancet, 395(10228), 945-947. https://doi.org/10.1016/S0140-6736(20)30547-X

Webb, M., \& Cox, M. J. (2004). A review of pedagogy related to ICT. Technology, Pedagogy and Education, 13(3), 235-285. https://doi.org/10.1080/14759390400200183

Wong, C. P., \& Ng, D. (2020). The roles of school leaders in developing future-ready learners: The case of Singapore. International Journal of Educational Management, 35(1), 249-269. https://doi.org/10.1108/IJEM-06-2020-0283

Zhang, W., Wang, Y., Yang, L., \& Wang, C. (2020). Suspending classes without stopping learning: China's education emergency management policy in the COVID-19 outbreak. Journal of Risk and Financial Management, 13(3), 55. https://doi.org/10.3390/jrfm13030055 


\section{Authors}

Margaret Cox, Emeritus Professor of Information Technology in Education based in both the Faculty of Education, Communication and Society and the Faculty of Dentistry, Oral and Craniofacial Sciences at King's College London. She has authored/co-authored over 250 publications in the field of technology enhanced learning and related areas of education, science, psychology, and physics over the last 40+ years. Email: Mj.cox@,kcl.ac.uk

Barry Quinn is Professor of Restorative Dentistry and Dental Education, School of Dentistry, Institute of Life Course and Medical Sciences, Faculty of Health and Life Sciences at the University of Liverpool, UK. His research examines interprofessional education, technology enhanced simulation with haptics and virtual reality, as well as evidence-based assessment of surgical skills and the use of deliberate practice to enhance performance in surgery. Email: barry.quinn@liverpool.ac.uk Email: barry.quinn@kcl.ac.uk

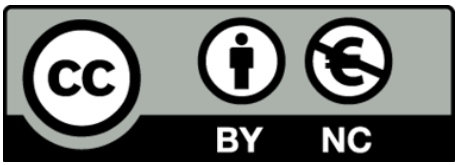

This work is licensed under a Creative Commons Attribution-NonCommercial CCBY-NC 4.0 International license. 